\title{
LOS AÑOS DE LAS DIFICULTADES: \\ LA CAJA DE AHORROS DE LA PROVINCIA DE CARTAGENA, NUEVA GRANADA, 1843-1853*
}

\author{
YEARS OF DIFFICULTIES: \\ THE CAJA DE AHORROS OF THE PROVINCE \\ OF CARTAGENA, NEW GRANADA, 1843-1853
}

\author{
Roicer Flórez Bolívar y Sergio Paolo Solano D. \\ Universidad de Cartagena, Cartagena de Indias, Colombia \\ $<$ rflorezb@unicartagena.edu.co $>$; <ssolanod@unicartagena.edu.co>
}

Resumen. Este artículo estudia las circunstancias que dieron origen a la Caja de Ahorro de la Provincia de Cartagena y su funcionamiento, políticas de captación de ahorradores, beneficios que prestaba y las limitaciones que encontró en la crisis económica por la que atravesaba la ciudad homónima, durante el periodo de 1843 a 1853. Concebimos la creación de esta institución como expresión del interés de las elites y las autoridades de esa provincia por controlar a la población y crear hábitos para una vida frugal. De igual forma, el análisis de los cuentahabientes ha servido para develar algunas características de las condiciones de vida de los distintos sectores sociales de ese puerto.

Palabras clave: Caja de Ahorros; sectores populares; orden; disciplina; crisis económica.

Abstract. The article analyzes the circumstances under which was created the first Caja de Ahorro of the province of Cartagena, and how it worked between 1843 and 1853. It also explores the benefits that this institution offered to its depositors and its policies to recruit savers, as well as the limitations and obstacles faced by this Caja de Ahorro in the middle of the economic crisis that characterized this province during the years under study. We argue that the elite and authorities of this province organized this type of saving institution as a mechanism to create frugal living habits and to shape and discipline the living style of Cartagena's popular sectors.

Key words: Caja de Ahorros; popular sectors; order; discipline; economic crisis.

Fecha de recepción: mayo de 2013. Fecha de aceptación: septiembre de 2013.

\footnotetext{
* Este artículo es resultado del proyecto de investigación Artesanos, Trabajo, Estilos de Vida y Reconocimiento Social en Cartagena, 1750-1850, inscrito en la vicerrectoría de investigaciones de la Universidad de Cartagena, Colombia. Agradecemos a los evaluadores por cada una de las recomendaciones que nos hicieron con el fin de mejorar este artículo.
} 


\section{PRESENTACiÓN}

$\mathrm{L}$ os sistemas e instituciones de captación de ahorros y préstamos tienen una larga historia en Hispanoamérica. Desde los montepíos creados durante la dominación española, pasando por las cajas de ahorros y terminando en los bancos modernos, estas instituciones se han creado con el fin de atraer dinero de ahorradores, otorgarles beneficios y garantizar la existencia de circulante. Montepíos y cajas de ahorros también fueron creados con el propósito de ejercer un control social y educar a la población en la vida frugal y previsiva.

Sólo en años recientes empezó a formarse una historiografía preocupada por estudiar los montepíos y cajas de ahorros como instituciones que precedieron y acompañaron la creación de los bancos modernos. En algunos casos los énfasis de los estudios se han hecho en los orígenes y evolución de estas instituciones, analizando sus características como unidades empresariales, sus labores crediticias, sus vínculos con el Estado. ${ }^{1}$ En otros casos el estudio de esos rasgos económicos de las cajas de ahorros se ha combinado con el análisis de los contextos económicos, sociales y políticos, y se ha subrayado la importancia de las políticas de estímulo del ahorro como un proyecto compartido por las elites hispanoamericanas interesadas en ejercer el control sobre la población y en estimular la vida frugal. El estudio de este aspecto tiene especial importancia para los casos de desencanto que comenzaron a manifestar las elites en relación con el ideario liberal que había impulsado la fase inicial de las nacientes repúblicas. No es casual que haya sido en los años de 1840 cuando empezaron a surgir las iniciativas de crear cajas de ahorros, pues en esos años es que el desencanto empezó a hacerse evidente.

Se sabe que las primeras iniciativas de creación de cajas de ahorros durante el siglo XIX se dieron en los territorios americanos que aún continuaban siendo colonias españolas, como eran los casos de Cuba y Puerto Rico, gracias a las decisiones de sectores de las elites que compartían el credo liberal en torno a los vínculos entre el progreso y la iniciativa individual. En parte, estas iniciativas replicaban lo que se venía haciendo en España, donde se crearon montepíos y cajas de ahorros desde el decenio de 1830. ${ }^{2}$ En 1840 se creó en La Habana una Caja de Ahorros por iniciativa de la Sociedad Económica de Amigos del País, y tres años más tarde también se creó en esa ciudad un monte de piedad independiente de aquella. ${ }^{3}$

\footnotetext{
${ }^{1}$ Romero, "Monte", 2008.

2 Martínez, “Cajas”, 2000, pp. 585-628, y "Montes”, 2006.

${ }^{3}$ Martínez, "Cajas”, 2008.
} 
En la Colombia de la primera mitad del siglo XIX el primer intento de captación de dinero de ahorradores fue el de la compañía de Giros y Descuentos de Bogotá de Judas Tadeo Landínez, creada en 1841, la que logró atraer a muchos ahorradores, ofreciendo $2 \%$ de intereses a los depositantes, el doble de lo que se ofrecía en el mercado. Un año después de creada y por la cantidad de especulaciones financieras que la compañía no pudo cubrir, en 1842 se declaró en quiebra, suscitando malestar y desconfianza entre los posibles ahorradores del país. ${ }^{4}$ Por eso, el Estado delegó en los gobiernos de las provincias en que estaba dividida la república la creación de cajas de ahorros. La primera que se fundó fue la Caja de Ahorros de Cartagena (1843). Luego siguieron las de Medellín (1844), Bogotá (1846), Santa Marta (1846), Santafé de Antioquia (1851) y otras. ${ }^{5}$ Aparte del interés de los años recientes por estudiar la Caja de Ahorros de Bogotá, ${ }^{6}$ las demás no han llamado la atención de los historiadores que han dedicado sus esfuerzos al estudio de la banca privada durante los años del federalismo (1857-1885) y la regeneración (1886-1899). ${ }^{7}$ Ese desinterés se explica por el desconocimiento de su existencia, los cortos años de vida de estas cajas de ahorros y porque no eran sociedades creadas por iniciativa privada, sino por decisiones gubernamentales.

Estas iniciativas hicieron parte del imaginario político de las elites de este país, que creían estar dando origen al nuevo hombre de la república con una nueva moralidad y una nueva valoración del trabajo y de la educación como vehículos para alcanzar el progreso. Durante esos primeros decenios de vida republicana la economía, la política y la moral estuvieron estrechamente ligadas en las iniciativas y discursos de los hombres ilustrados decimonónicos. ${ }^{8}$ La valoración positiva del trabajo también creó una "nueva sensibilidad" sobre la pobreza, ya que al ser desacralizada fue puesta en el orden de lo práctico y se trató entonces de organizarla atacando la ociosidad de los vagabundos, asistiendo y encerrando a los mendigos y enfermos y convirtiendo a los pobres en seres útiles para la sociedad mediante el trabajo. Es decir, vagos, pobres y mendigos fueron tratados como problemas de policía y de orden público. ${ }^{9}$

Teniendo en cuenta lo anterior, el presente artículo estudia la Caja de Ahorros de la Provincia de Cartagena ${ }^{10}$ entre 1843 y 1853. Esta formó par-

${ }^{4}$ Arango, Judas, 1981.

${ }^{5}$ Correa, "Banca", 2009, pp. 15-44.

${ }^{6}$ Sowell, "Caja”, 1999, pp. 217-250, y López-Uribe y Güiza, “Caja”, 2011.

${ }^{7}$ Meisel, "Bancos", 1990, pp. 69-96, y Botero, "Moneda", 2011, pp. 53-81.

${ }^{8}$ Solano y Flórez, "Política", 2013, pp. 17-18.

${ }_{9}^{9}$ Jurado, Vagos, 2004, p. 112; Castro, Caridad, 2007, pp. 63-108; Pérez, Hijos, 2005, pp. 189257; Teitelbaum, Control, 2008, pp. 31-170, y Sagastume, Trabajo, 2008, pp. 249-320.

${ }^{10}$ La Provincia de Cartagena comprendía el territorio de la región Caribe colombiana situado entre el margen occidental del bajo curso del río Magdalena y el golfo de Urabá, en la frontera 
te de un conjunto de estrategias tanto para paliar la crisis por la que atravesaba esa ciudad portuaria como para intentar educar, controlar, sujetar y corregir a la población por parte del Estado durante la primera mitad del siglo XIX. En ese sentido la Caja de Ahorros obedeció a un proyecto político de control social por parte de gobiernos desencantados del proyecto liberal, que cifraba todas las esperanzas en la formación de ciudadanos para ejercitar la política. Por eso, después de la guerra de los Supremos (1839-1842), los gobiernos pretendieron estimular entre la población el apego al trabajo, a la temperancia y al ahorro como vías para alejarla de la vida política. ${ }^{11}$

La idea central que organiza nuestra reflexión es que la corta existencia de la Caja de Ahorro se debió al conjunto de problemas que tuvo que enfrentar, tanto de índole nacional (crisis económica, déficit del tesoro del Estado, decadencia del comercio de exportación, bajos salarios, inestabilidad política), como local (caída de la población de Cartagena, pérdida del monopolio sobre el comercio exterior del país, fin del flujo del situado fiscal, cierre de las obras de defensa como espacio de demanda laboral). La conjunción de estos problemas obstaculizó el desarrollo de la Caja de Ahorros, y diez años después de haber sido creada cerraba sus servicios de forma definitiva.

Para desarrollar esa idea, el artículo está dividido en cuatro partes. En la primera analizamos algunas características socioeconómicas de Cartagena en las primeras décadas del siglo XIX; en la segunda destacamos la formación de la Caja como mecanismo de educación, regulación y control de los sectores populares; en la tercera hacemos una radiografía de los ahorradores y solicitantes de préstamos con el fin de valorar si efectivamente se alcanzaron los objetivos que se buscaban con su fundación, y en la cuarta señalamos las razones que llevaron al cierre de la Caja en 1853.

con Panamá. Durante la colonia y la primera mitad del siglo XIX recibió ese nombre. En el tercer cuarto de esa centuria se llamó Estado Soberano de Bolívar. A partir de 1886 se lo conoció como Departamento de Bolívar, o Bolívar Grande. Abarcaba los territorios de los actuales departamentos del Atlántico, Bolívar, Sucre, Córdoba y San Andrés Islas, con una extensión de 65300 kilómetros cuadrados. Durante los años que estudiamos en este artículo, Nueva Granada se dividía en provincias; estas se dividían en cantones y estos en distritos parroquiales. Al frente de la provincia estaba un gobernador nombrado por el presidente, y los colegios electorales elegían de forma indirecta una Cámara Provincial. Cada cantón era dirigido por un jefe político, y los distritos por alcaldes. Jefes políticos y alcaldes eran nombrados por el gobernador provincial. Solano y Flórez, “Ordenamiento", 2008, pp. 67-121.

${ }^{11}$ Solano, "Empresarios", 1995, pp. 9-38. 


\section{CONDICIONES ECONÓMICAS Y SOCIALES DE CARTAGENA EN LA PRIMERA MITAD DEL SIGLO XIX}

Durante la colonia Cartagena de Indias fue uno de los puertos más importantes de la monarquía española en América. A lo largo de la segunda mitad del siglo XVIII su economía se dinamizó gracias a la reforma militar emprendida por Carlos III, lo que se tradujo en grandes inversiones en obras de fortificación como murallas, cortinas y baluartes, arsenales y astilleros. ${ }^{12}$ Además, como el sostenimiento del personal militar asignado a la plaza y la financiación de las fortificaciones demandaban un gasto anual elevadísimo que las rentas de la ciudad no podían cubrir, otras provincias de Nueva Granada, Quito y México tenían que aportar el llamado situado fiscal. ${ }^{13}$

Gracias a esta condición de plaza fuerte y al monopolio que tenía sobre el comercio del Nuevo Reino de Granada con España y otras colonias, en esta ciudad se formó un dinámico sector de comerciantes compuesto por españoles y criollos blancos. Inversiones en tráfico de mercaderías, embarcaciones, haciendas, casas y esclavos permitían a este sector vivir holgadamente y coronar el ápice de la pirámide social. De ahí devenía la posibilidad de disfrutar de los principales cargos administrativos de la ciudad y de la oficialidad del ejército fijo que la defendía. ${ }^{14}$ También existía una importante franja de blancos pobres que no habían corrido con igual suerte que los anteriores, pero que disfrutaban de la prestancia que les daba esa condición sociorracial. Al lado de estos se había formado un importante sector de familias de color libres, las que también formaban parte de los sectores medios de la sociedad gracias al trabajo de sus miembros, en su mayoría artesanos notables, y a un estilo de vida que tenía aceptación y reconocimiento social..$^{15}$ Por debajo de estos estaba la plebe, gente libre de color que ejercía diversos oficios no calificados, y en la base de la pirámide social los esclavos, que para finales del siglo XVIII habían perdido importancia en la vida económica de la ciudad. ${ }^{16}$

No obstante, durante el siglo XIX el crecimiento económico y demográfico de Cartagena llegó a su fin como consecuencia de la crisis generada por la guerra de Independencia (1810-1821), de la pérdida del monopolio que ejerció sobre el comercio exterior del Nuevo Reino de Granada, y

${ }^{12}$ Serrano, Fortificaciones, 2004; Marchena, Institución, 1982, pp. 268-271, y Kuethe, "Milicias", 2005, pp. 101-126.

${ }^{13}$ Meisel, “iSituado?”, 2005, pp. 61-124, y Serrano, "Economía”, 2006, pp. 75-96.

${ }^{14}$ Ripoll, Elite, 2006, pp. 40-98; Múnera, Fracaso, 1998, pp. 53-110, y Helg, Libertad, 2011.

${ }^{15}$ Solano, "Sistema", 2013, pp. 92-139.

${ }^{16}$ Aguilera y Meisel, Tres, 2009, pp. 9-54. 
por la catástrofe demográfica causada por la peste del cólera en $1849 .^{17}$ Por ejemplo, se calcula que Cartagena tenía en 1812 alrededor de 20000 habitantes. Según el censo de 1843 su población se había reducido aproximadamente a 11000 personas, y el censo de 1870 sólo registró 8613 habitantes. ${ }^{18}$ Además del costo humano que pagó Cartagena, lo que más perjudicó sus posibilidades de crecimiento en el largo plazo fueron las nuevas condiciones económicas que surgieron con la independencia al ser abolidos el situado y el monopolio que ejercía sobre el comercio exterior. ${ }^{19}$ Esta catástrofe demográfica y económica no pasó inadvertida para los viajeros que arribaron a Cartagena en la primera mitad del siglo XIX. Por ejemplo, August Le Moyne, un viajero francés que visitó la ciudad en 1839, consignó: "Hoy la ciudad, venida a muy menos, ve desmoronarse sus murallas, cuyos cañones, inútiles ya, fueron vendidos; el único comercio que por ella se hace con el interior de Nueva Granada ha quedado reducido a nada o casi nada[...] Cartagena, que en su época de esplendor contaba con cerca de 30000 almas, no tiene hoy más de 10 000." ${ }^{20}$ La elite blanca seguía concentrando las actividades económicas más rentables y el poder. Ocupaban la mayoría de los cargos de poder político y económico, y ahora los británicos, los estadunidenses, los franceses y otros extranjeros habían reemplazado a los españoles en el comercio. Durante las primeras décadas del siglo XIX estos extranjeros reprodujeron el esquema de la sociedad colonial al lograr el predominio de los negocios y al integrarse a las elites casándose con cartageneras prestantes. ${ }^{21}$ Pero la mayoría de la población estaba constituida por gente de color que se ejercitaba en diversos oficios manuales. ${ }^{22}$ La mayor parte de esta eran mujeres, presencia mayoritaria que se había manifestado desde el periodo colonial y que se profundizó con la guerra por la independencia al morir muchos hombres en los campos de batalla o por epidemias durante la estadía en las tropas. ${ }^{23}$ Ese mismo año, casi 600 negros eran esclavos, cifra que en 1851 se había reducido a 194, con predominio de mujeres (143 esclavas y 51 esclavos). ${ }^{24}$ Estos hombres y mujeres negros y pardos se caracterizaban por el desem-

${ }^{17}$ Ibid.; Meisel, Perdió, 2009, pp. 89-112, y Fernández, "Participación”, 2010, pp. 53-149.

${ }^{18}$ Pombo, Recopilación, 1845, pp. 464-465, y en Biblioteca Luís Ángel Arango (en adelante BLAA), Gaceta de Bolívar, 7 de enero de 1872.

${ }_{19}^{19}$ Para el impacto negativo de esta situación sobre los artesanos, véase Solano, "Oficios", 2012, pp. 113-144.

${ }^{20}$ Deavila y Guerrero, Cartagena, 2011, p. 162.

${ }^{21}$ Ripoll, Elite, 2006, p. 133.

${ }^{22}$ Véanse las impresiones de los viajeros Gosselman (1826) y Tanco (1851) en Deavila y Guerrero, Cartagena, 2011, pp. 111 y 181.

${ }^{23}$ Helg, Libertad, 2011, p. 370, y Aguilera y Meisel, Tres, 2009, pp. 55-104.

${ }^{24}$ BLAA, La Democracia, 13 de febrero de 1851. 
peño de una variedad de actividades laborales, como lo resaltó en 1823 Gaspar-Theodore Mollien:

La población de Cartagena se compone casi toda ella de hombres de color en su mayor parte marineros o pescadores. Hay algunos que tienen tiendas de mercería o de comestibles; otros ejercen oficios útiles; industrias incipientes que para que prosperen no necesitan más que un poco de estímulo y de competencia. Trabajan muy bien la concha, son excelentes joyeros, buenos carpinteros, magníficos zapateros, sastres regulares, mediocres ebanistas, herreros más bien que cerrajeros, albañiles carentes de ideas de proporción, malos pintores, pero eso sí, son aficionadísimos a la música. ${ }^{25}$

Las mujeres trabajaban en diversos oficios como servicio doméstico, vendían mercancías en las calles y los mercados; lavaban ropa; administraban hospedajes, tabernas y pequeñas tiendas; transportaban mercancías entre la ciudad y sus alrededores; eran costureras, cocineras, planchadoras, arperas, tabaqueras.

Para la mayor parte de los trabajadores manuales que durante el siglo XVIII habían encontrado trabajo en las obras de defensa, la difícil situación que se anunció desde el primer decenio del siguiente siglo se profundizó desde los años de 1820 en adelante,${ }^{26}$ cerrándose esa fuente de ocupación. Un sector medio formado por artesanos y pulperos de color sufrió esa situación, pues el Estado dejó de ser un espacio de contratación en el rubro de las obras de defensa. ${ }^{27}$ Sin embargo, con el nuevo Estado republicano surgió la posibilidad de competir por espacios políticos y cargos públicos. Un sector de pardos libres empezó a tener un protagonismo político de primer orden gracias al disfrute de la ciudadanía, a la creación de redes políticas y a los procesos electorales. ${ }^{28}$ Es decir, se pasó de prestar un servicio útil al Estado colonial a una situación en la que la sobrevivencia dependía de ubicarse en la burocracia. Y esto implicaba estar sometido a los avatares de las finanzas públicas y al posible estancamiento y rebaja de los sueldos en concordancia con las crisis fiscales. ${ }^{29}$ Los ejercicios de algunos historiadores con los índices de precios y salarios durante la primera mitad del siglo XIX sugieren una caída del producto interno bruto per cápita en $0.3 \%$ en relación con los últimos años de la colonia, ${ }^{30}$ lo que resentía de

${ }^{25}$ Deavila y Guerrero, Cartagena, 2011, p. 89.

${ }^{26}$ O'Byrne, "Desabastecimiento", 2013, pp. 59-78.

${ }^{27}$ Solano, "Artesanos", 2012, pp. 5-60.

${ }^{28}$ Helg, Libertad, 2011, pp. 287-409; Conde, Buscando, 2009, pp. 44-58, y Flórez y Solano, "Educando", 2010, pp. 605-633.

${ }^{29}$ Junguito, "Finanzas", 2010, p. 46.

${ }^{30}$ Kalmanovitz y López, Cuentas, 2009, pp. 77-80. 
forma significativa la economía de la mayoría de la población, que vivía en los límites de la pobreza.

A esta situación local se unía la difícil situación económica de todo el país. Y es que como consecuencia de la prolongada guerra de Independencia, un Estado republicano con una precaria situación fiscal y una alta deuda interna y externa, la depreciación del medio circulante y el descrédito en que habían caído las emisiones de papel moneda ${ }^{31}$ y un comercio exterior prácticamente paralizado, la economía de la Nueva Granada en la primera mitad del siglo XIX se encontraba estancada, y ofrecía pocas oportunidades a los habitantes. ${ }^{32}$ De hecho, el sistema de crédito de origen colonial (censos y capellanías) se mostró rígido frente a las exigencias de una economía necesitada de capitales. Los poseedores de capital líquido aprovechaban esta situación para prestar a altas tasas de interés $(6 \%)$, y por esta vía acceder a bienes raíces urbanos y rurales por incumplimiento del deudor y el vencimiento de los términos de los préstamos. ${ }^{33}$ Esto lo ilustra el número de obligaciones hipotecarias registradas en la notaría primera de Barranquilla entre 1815 y 1853. En efecto, entre 1815 y 1836 el promedio anual de hipotecas sobre bienes raíces fue de cuatro. Pero entre 1837 y 1853 ese promedio se disparó a $20,{ }^{34}$ cifra significativa para una población que estaba por debajo de los 5000 habitantes. Muchas de estas obligaciones hipotecarias sobre bienes raíces fueron otorgadas por personas humildes que corrían el riesgo de quedarse sin casa.

Aunque todavía está por estudiarse lo que estaba sucediendo en Cartagena respecto de la movilidad comercial de las edificaciones y solares urbanos, todo parece indicar que algunos comerciantes hallaron en el rubro de las obligaciones con hipotecas un mecanismo seguro para invertir sus dineros a mediano plazo. Antes de que se aprobara la desamortización de bienes de manos muertas (1861) por parte del gobierno central de los Estados Unidos de Colombia, el acceso a préstamos estaba muy restringido, y las personas que necesitaban dinero estaban sometidas a una alta tasa de interés (6\%), en una ciudad en la que 275 bienes urbanos (casas altas y bajas, y solares) se encontraban bajo el régimen de censos y capellanías ${ }^{35}$ esta cifra es significativa, pues representaba $25 \%$ del total de las viviendas, excluyendo al barrio de Santa Catalina (La Catedral). ${ }^{36}$ Luego de la apro-

${ }^{31}$ Meisel, "Patrón”, 1990, pp. 7-21.

${ }^{32}$ Kalmanovitz, "Consecuencias", 2008, pp. 207-233, y Junguito, "Finanzas", 2010, pp. 41-68.

${ }^{33}$ Para los efectos de esta situación en el área de influencia de Cartagena, véase Caballero, "Ventas", 2008, pp. 229-252, y "Créditos", 2011, pp. 145-164

${ }^{34}$ Archivo Histórico del Departamento del Atlántico, Sección I. Notarias, Notaría Primera de Barranquilla, Libros Protocolos, 1815-1817, 1823-1827, 1828, 1834-1836, 1837, 1838-1839, 1840, 1841-1842, 1843, 1844, 1845, 1846, 1847, 1848, 1849, 1850, 1851, 1852, 1853, tomos únicos.

${ }^{35}$ Cruz, "Remates", 2014, y Meisel y Salazar, "Desamortización”, 2011.

${ }^{36}$ Tovar, "Historiografía", 1998, p. 56. 
bación de la desamortización que permitió la circulación comercial de muchos bienes raíces urbanos y rurales, algunos comerciantes se hicieron de buena parte de los bienes raíces que habían estado bajo aquella condición. Ese fue el caso del italiano Juan Mainero y Trucco. ${ }^{37}$

La conjunción de estas situaciones económicas nacionales y locales, más los temores políticos que despertaba la participación en la vida pública de la gente común, la cual alcanzó un primer cenit con la guerra de los Supremos (1839-1842), generó un pesimismo entre las elites y las autoridades de la provincia de Cartagena, colocando el énfasis de los asuntos del gobierno en el control social y en generar una ética valorativa del trabajo, la austeridad y el ahorro. ${ }^{38}$ Durante los años 1820 y 1830, en el imaginario de las elites latinoamericanas la nación aparecía como una construcción incluyente, en la que la heterogeneidad y la ausencia de cohesión que a ella se vinculaba, se irían esfumando paulatinamente por obra de unas benéficas instituciones y una educación orientada a la formación de ciudadanos. ${ }^{39}$ Es decir, las elites de la década de 1840 creían, al igual que sus pares de las dos décadas anteriores, que el Estado debía asumir una participación como educador y corrector; sin embargo, se diferenciaban en que las primeras hacían énfasis también en su papel de controlador y castigador para establecer el orden, convirtiéndose el control social de la población en un asunto prioritario. ${ }^{40}$

\section{DÉCADA DE 1840: CONTROL SOCIAL, TRABAJO Y VIRTUDES. La Caja de Ahorros}

Como consecuencia de lo anterior, en la década de 1840 se organizó en Cartagena un conjunto de instituciones entre las que sobresalían la Casa de Beneficencia, el Hospital de Caridad, el cuerpo de policía, la Sociedad de Fomento Industrial y la Caja de Ahorros. ${ }^{41}$ Asimismo, se endurecieron las penas contra la vagancia y la mendicidad y se establecieron mayores controles sobre las casas de juego, billares y galleras al ser considerados lugares aptos para el desorden. ${ }^{42}$ En 1840 el gobernador de la provincia de Cartagena manifestaba que la Casa de Beneficencia debía llamar la atención de la Cámara Provincial porque "la humanidad y la moral pública

${ }^{37}$ Molina, Empresarios, 1998, pp. 74-114.

${ }^{38}$ Safford, Ideal, 1989, pp. 86-121, y Rojas, Repúblicas, 2009, pp. 319-359.

${ }^{39}$ Quijada, “iNación?”, 2003, pp. 287-315.

${ }^{40}$ Conde, Buscando, 2009, p. 91.

${ }^{41}$ BLAA, Semanario de la Provincia de Cartagena (en adelante SPC), 27 de septiembre de 1840 y 5 de noviembre de 1843.

${ }^{42}$ Ibid., 25 de agosto y 5 de noviembre de 1843. 
hablan de un modo elocuente a favor de este útil y filantrópico establecimiento, en el cual encontraban asilo y socorro, educación y oficio, el huérfano desamparado y el indigente que vive de la caridad publica y cuya desgraciada suerte conmueve a cada paso la sensibilidad de los ciudadanos". ${ }^{43}$ Tres años más tarde, otro gobernador celebraba el establecimiento de la Caja de Ahorros en Cartagena, porque:

Pocas instituciones darán resultados morales tan trascendentales como esta, pues por su medio se fomenta el amor al trabajo, se crean hábitos de economía, de sobriedad y de orden, y se asegura consiguientemente el bienestar de las familias y el reposo de la sociedad. La institución de cajas de ahorros [...] propende a la industria y hombría de bien de los solteros para poder establecerse en nuevo estado, y de los casados para mantener y criar a sus hijos. ${ }^{44}$

Las reflexiones hechas por estos gobernadores en esa década sobre la presencia de huérfanos, indigentes, mendigos, vagos, solteros, domésticos libres y la organización de la Casa de Beneficencia y la Caja de Ahorros en Cartagena estaban a tono con las discusiones que adelantaban en ese momento las elites de los nacientes Estados hispanoamericanos sobre el progreso y la consolidación de las repúblicas. Estas pensaban que para alcanzar estos objetivos era necesario ejercer un mayor control social y político sobre la población y generar una nueva valoración del trabajo productivo y del ahorro, y disminuir la participación de la gente común y corriente en la política.

Todas estas medidas potenciaron la actuación del Estado buscando aprovechar los recursos que encarnaba el trabajo de la población en función de un nuevo orden basado en la utilidad común. En consecuencia, la población que hasta entonces había sido ingobernable o improductiva (pobres, mendigos, vagos, ociosos y mal entretenidos) fue sometida a medidas de represión y asistencia. En última instancia, este proyecto abogaba por una educación que corrigiera y disciplinara a la población en hábitos que hasta el momento no conocía: decencia, diversiones modestas y sanas. ${ }^{45}$ Para alcanzar estos fines era necesario generar y desarrollar nuevos hábitos como el orden, la disciplina, la moderación, el destierro de los vicios y las pasiones ${ }^{46}$ como lo advertía el gobernador de la provincia de Cartagena al ser fundada la Caja de Ahorros en 1843, quien la calificaba como una "benéfica institución de los pueblos civilizados, llamada a con-

${ }^{43}$ Ibid., 27 de septiembre de 1840.

${ }^{44}$ Ibid., 5 de noviembre de 1843.

${ }^{45}$ Hensel, Vicios, 2006, pp. 45-71; BLAA, SPC, 19 de septiembre de 1847, y El Fanal, 19 de marzo de 1849.

${ }^{46}$ Hensel, Vicios, 2006, pp. 45-71. 
tribuir a la regeneración moral del nuestro, no menos que a su mejora material". ${ }^{47}$ Este mismo discurso era sostenido cuatro años más tarde por otro gobernador:

el establecimiento de la caja de ahorros ha contribuido en alguna manera a aliviar la suerte del pueblo, como que su misión es toda de orden, economía y moralidad. Además, toda persona medianamente instruida sabe que la institución de las cajas de ahorros tiene por objeto inducir y acostumbrar a las clases trabajadoras a economizar y guardar, y con esto fomentar las buenas costumbres, el bienestar individual y la riqueza pública. Poder volver los ojos a la caja de ahorros y hallar allí el fruto de nuestra previsión y de nuestras economías! Por cualquier lado que se mire esta institución siempre se le encontrará útil, moral, santa, digna en fin de todo pueblo culto y morigerado. ${ }^{48}$

Fue en ese contexto de pesimismo generalizado y de estancamiento de la economía y de la población de Cartagena en el que se creó la Caja de Ahorros, luego de terminada una confrontación civil en Nueva Granada conocida como la guerra de los Supremos (1839-1842) e implantada la Constitución política de 1843 en la que se definió que la función del Estado era regular el orden social. Esta Caja de Ahorros tenía dos propósitos centrales. La primera era de carácter filantrópico al pretender cambiar el comportamiento y las actitudes de los grupos menos favorecidos, y la segunda era estimular la actividad comercial a través de la distribución de capital a bajo interés. ${ }^{49}$

Para su funcionamiento, lo primero que se hizo fue crear una junta directiva que se denominó Junta de Administradores. Posteriormente, esta junta creo la de Inversión y Superintendencia y estableció dos reglamentos. Uno para el manejo y contabilidad de la Caja y otro para la recepción de los depósitos. En el primero se estableció que los fondos de la Caja podían emplearse en deuda de la república; descuentos; empréstitos o avances a corporaciones y particulares. De igual modo, podían emplearse en cualquier otro negocio que ofreciera alguna ventaja al establecimiento a juicio de la Junta de Inversión y Superintendencia, con acuerdo de la de los administradores. Los giros se hacían a $2 \%$ para los descuentos y a $1.5 \%$ mensual para los préstamos. ${ }^{50} \mathrm{En}$ el caso del reglamento para la recepción de depósitos se estipuló que se harían todos los domingos, de las doce del día a las dos de la tarde. Inicialmente se estableció que los depósitos

\footnotetext{
${ }^{47}$ BLAA, SPC, 21 de junio de 1844.

${ }^{48}$ Ibid., 29 de agosto de 1847.

${ }^{49}$ Sowell, "Caja", 1999, p. 219.

${ }^{50}$ BLAA, SPC, 2 de junio de 1844.
} 
tendrían un mínimo de dos reales ${ }^{51}$ y como máximo dos pesos. Posteriormente, aunque se mantuvo el depósito mínimo, fue abolida la cantidad máxima y se dio vía libre a cualquier cuantía.

Como la Caja tenía el carácter de provincial, en septiembre de 1846 la Cámara ordenó que en cada uno de los distritos de la provincia se estableciera una subalterna de la capital con el nombre de receptoría de la Caja de Ahorros, y para su establecimiento los jefes políticos en las cabeceras de los cantones y los alcaldes en las de los distritos convocarían a los vecinos a una reunión, en la cual los excitarían a fundarla. ${ }^{52}$

\section{AHORRADORES SOLICITANTES DE PRÉSTAMOS}

El 30 de junio de 1844 se inició la admisión de depósitos. ${ }^{53}$ El análisis de los ahorradores en los semestres que transcurrieron entre junio de $1846 \mathrm{y}$ diciembre de 1849 (véanse cuadros 1 y 2) permite observar varios aspectos. El primero es que la Caja de Ahorros es una ventana que permite examinar, por un lado, algunas características de la sociedad y de la economía de Cartagena al mostrar las diferentes actividades laborales desempeñadas por hombres y mujeres para su subsistencia y, por el otro, la crisis económica que enfrentó la ciudad en la primera mitad del siglo XIX.

Otro aspecto que se resalta es que los mayores ahorradores eran los menores y las mujeres. ${ }^{54}$ De los 1906 ahorradores que tuvo la Caja en este periodo, 864 eran menores; ${ }^{55}$ de las mujeres, 264 eran casadas; 161 eran costureras; 95 eran viudas y 50 eran planchadoras, ejecutantes de arpas, cocineras, tabaqueras, lavanderas, pulperas, directoras y porteras del colegio. En términos porcentuales, los menores representaban $45 \%$; las casadas, $12.5 \%$; las costureras, $8.4 \%$; las viudas, $4.9 \%$, y el resto, $2.6 \%$. Es decir, menores y mujeres eran $73.4 \%$ de los ahorradores.

${ }^{51}$ Durante la primera mitad del siglo XIX, la unidad monetaria con que usualmente se hacían los pagos en Nueva Granada era el peso fuerte. Hasta 1846, un peso equivalía a ocho reales, pero a partir de 1847 equivalía a diez. López-Uribe y Güiza, "Caja”, 2011, pp. 1-48.

${ }^{52}$ BLAA, $S P C, 4$ de octubre de 1846.

${ }^{53}$ Ibid., 7 de junio de 1844 .

${ }^{54}$ Es preciso señalar que esto no fue un fenómeno exclusivo de la Caja de Ahorros de Cartagena, ya que las cajas de Bogotá, Buenos Aires y España presentaban la misma dinámica en el siglo XIX. Al respecto, véanse López-Uribe y Güiza, "Caja", 2011; Mateo "Respuesta", 2008; Martínez, "Cajas", 2000, y "Montes", 2006.

${ }^{55}$ Aunque a lo largo de todo el siglo XIX existió en Cartagena el trabajo infantil, las fuentes primarias muestran que los menores que ahorraban en la Caja pertenecían a los sectores medios y altos de la sociedad. Por ejemplo, en 1850 el comerciante y miembro del partido conservador, José María de la Espriella, solicitaba su retiro, el de su esposa, su madre y de sus ocho hijos. Al respecto, véase BLAA, "Petición”, La República, 3 de octubre de 1850. 
CUADRO 1. DISTRIBUCIÓN DE LOS AHORRADORES, 1846

\begin{tabular}{lrlr}
\hline Ahorradores & Número & \multicolumn{1}{c}{ Ahorradores } & Número \\
Menores & 220 & Cocineras & 3 \\
Casadas & 39 & Eclesiásticos & 2 \\
Costureras & 36 & Lavanderas & 2 \\
Empleados & 17 & Profesores de música & 2 \\
Negociantes & 14 & Albañiles & 1 \\
Viudas & 14 & Canal del dique & 1 \\
Abogados & 12 & Farmaceutas & 1 \\
Esclavos & 7 & Hacendados & 1 \\
Agricultores & 6 & Impuesto a favor del hospital & 1 \\
Militares & 6 & Impuesto a favor de las artes & 1 \\
Sastres & 5 & Impresores & 1 \\
Ancianas & 4 & Navegantes & 1 \\
Médicos & 4 & Plateros & 1 \\
Carpinteros & 3 & Preceptores & 1 \\
Propietarios & 3 & Pulperas & 1 \\
& & & \\
\hline
\end{tabular}

Fuente: BLAA, SPC, 19 de julio de 1846.

Ahora bien, se nota una tendencia decreciente en la participación de los menores como ahorradores al pasar de $53.7 \%$ en 1846 a $37.3 \%$ en 1849 . Mientras que las mujeres transitaron de 10.6 a 30.6\%. No obstante, debemos precisar que, en el caso de este grupo, algunas pertenecían a la población económicamente activa (costureras, tabaqueras, lavanderas, cocineras, arperas), cuyo aporte como ahorradoras era de 11\%, y otras aparecen sólo con sus estados civiles (casadas y viudas) sin especificar oficio, y su participación era de $17.4 \%$. De esta forma, si sumamos la contribución de los menores $(45 \%)$ con la de las casadas y las viudas, podemos concluir que los principales ahorradores de la Caja pertenecían a la población económicamente inactiva de Cartagena, grupo que entre 1846 y 1849 constituyó $62.4 \%$ del total.

La activa intervención de las mujeres como ahorradoras en la Caja $(28.4 \%)$ confirma que la mayor parte de la población de la ciudad era femenina y que desempeñaba un papel esencial en su estructura económica al ser, muchas de ellas, cabezas de familia. Pero también muestra que muchas, por los oficios desempeñados, tenían poca capacidad de ahorro. Por ejemplo, dentro de las diferentes actividades laborales que ejercían, las que sobresalían como ahorradoras eran las costureras. 
CUADRO 2. AHORRADORES, 1846-1849

\begin{tabular}{|c|c|c|c|c|c|}
\hline Ahorradores & 1846 & 1847 & 1848 & I. 1849 & II. 1849 \\
\hline Abogados & 12 & 15 & 20 & 16 & 15 \\
\hline Agricultores & 6 & 1 & 1 & 2 & 2 \\
\hline Albañiles & 1 & 2 & 2 & - & - \\
\hline Ancianas & 4 & - & - & 1 & 1 \\
\hline Arperas & - & - & 1 & 1 & - \\
\hline Canal del dique & 1 & - & - & - & - \\
\hline Carpinteros & 3 & - & 2 & 1 & 2 \\
\hline Casadas & 39 & 46 & 62 & 44 & 48 \\
\hline Cocineras & 2 & 3 & 5 & 1 & - \\
\hline Cónsules & - & - & 1 & 1 & 1 \\
\hline Costureras & 36 & 25 & 38 & 29 & 33 \\
\hline Dependientes & - & - & 1 & 1 & 1 \\
\hline Depósitos judiciales & - & - & - & 1 & 1 \\
\hline Directoras de colegios & - & - & 1 & - & - \\
\hline Eclesiásticos & 2 & 2 & 2 & 2 & - \\
\hline Empleados & 17 & 14 & 14 & 14 & 16 \\
\hline Esclavos & 7 & 5 & 7 & 6 & 5 \\
\hline Escribanos & - & - & - & - & 1 \\
\hline Estudiantes & 1 & 2 & 2 & - & - \\
\hline Establecimiento público & - & - & - & 8 & 7 \\
\hline Farmaceutas & 1 & 2 & 1 & - & - \\
\hline Forzados & - & - & 1 & - & - \\
\hline Hacendados & 1 & 2 & 3 & 4 & 4 \\
\hline Ingenieros & - & - & 2 & - & - \\
\hline Imp. a favor del hospital & 1 & 1 & 1 & - & - \\
\hline Imp. a favor de las artes & 1 & 1 & - & - & - \\
\hline Impresores & 1 & 1 & - & - & 2 \\
\hline Jefaturas políticas & - & - & 1 & - & - \\
\hline Lavanderas & 2 & 4 & 2 & 4 & 2 \\
\hline Médicos & 4 & 3 & 5 & 4 & 5 \\
\hline- & 220 & 199 & 197 & 120 & 128 \\
\hline- & 6 & 2 & 4 & 1 & 1 \\
\hline Mortuorias & - & - & - & - & 1 \\
\hline Navegantes & 1 & 1 & 2 & 1 & 1 \\
\hline Negociantes & 14 & 23 & 26 & 18 & 19 \\
\hline- & 1 & - & - & 3 & 1 \\
\hline
\end{tabular}




$\begin{array}{lccccc}\text { Ahorradores } & 1846 & 1847 & 1848 & \text { I. } 1849 & \text { II. } 1849 \\ \text { Planchadoras } & - & - & 1 & - & - \\ \text { Pintores } & - & - & 2 & 1 & 1 \\ \text { Porteras del colegio } & - & - & 1 & - & - \\ \text { Preceptores } & 1 & - & 1 & 1 & 1 \\ \text { Presidiarios } & - & - & 1 & - & - \\ \text { Profesores de música } & 2 & - & - & - & - \\ \text { Propietarios } & 2 & - & 1 & - & - \\ \text { Pulperas } & 1 & - & - & 2 & 2 \\ \text { Receptorías } & - & - & 1 & 1 & 1 \\ \text { Reclusos } & - & - & - & 1 & 1 \\ \text { Sastres } & 5 & 2 & 3 & 4 & 8 \\ \text { Sirvientes } & - & - & 1 & 1 & - \\ \text { Tabaqueras } & - & - & 2 & 4 & 4 \\ \text { Tesorerías cantonales } & - & - & 1 & - & - \\ \text { Testamentarias } & - & - & - & 3 & - \\ \text { Viudas } & 14 & 14 & 21 & 22 & 24 \\ \text { Zapateros } & - & 1 & 2 & - & - \\ & & & & & \end{array}$

Fuentes: BLAA, SPC, 19 de julio de 1846; 18 de julio de 1847; 23 de enero de 1848; 5 de agosto de 1849, y 29 de enero de 1849 .

Asimismo, es destacable la actuación de las casadas. Es probable que la relevancia de este grupo pueda estar relacionada con la gran actividad en el núcleo familiar, puesto que las mujeres podían tener una noción más explícita y clara del concepto de previsión para la familia. Para López y Güiza y Martínez, parte del comportamiento de las mujeres casadas al mantener ahorros en la Caja de Bogotá y en las de España puede estar sustentada en las ideas introducidas en la época respecto a sus labores, responsabilidades y oficios a los que debían dedicarse. Además, también coligen que la crianza y educación dada a las mujeres de la época les permitía tener una mentalidad más amplia respecto al ahorro como fondo previsivo para situaciones no previstas (enfermedad, guerra, decadencia económica, matrimonios). ${ }^{56}$

En el caso de los hombres, sobresalen los comerciantes (5.2\%) lo que muestra la importancia de esta actividad para la economía de la ciudad, aun en medio de la crisis. Otros grupos que se destacan son los abogados (4.6\%), los empleados públicos (3.9\%) y los esclavos (1.6\%). Aunque fueron

\footnotetext{
${ }^{56}$ López-Uribe y Güiza, “Caja”, 2011, y Martínez, “Cajas”, 2000.
} 
pocos los esclavos que se vincularon como ahorradores, es significativo que, a pesar de las condiciones adversas en que se encontraban, algunos tenían la capacidad de ahorrar, suponemos que para alcanzar su libertad o la de algún familiar. Asimismo, se observa la escasa vinculación de eclesiásticos $(0.4 \%)$, agricultores $(0.6 \%)$, militares $(0.7 \%)$ y artesanos $(2.5 \%)$. De estos grupos llama la atención la poca participación de los artesanos y los militares, dos sectores clave en la estructura socioeconómica de Cartagena desde la segunda mitad del siglo XVIII. De hecho, en 1779-1780 los artesanos constituían el grupo socioocupacional más significativo en la ciudad por su peso en la población económicamente activa. En 1777 había un total de 772 artífices, que representaban $34.7 \%$ de la población económicamente activa..$^{57}$

Entre los pocos artesanos que se vincularon como ahorradores, la mayoría eran sastres, carpinteros, albañiles, plateros e impresores. No figuran armeros, herreros, fundidores, calafates y carpinteros de ribera, sectores con una contribución trascendente en la economía de la ciudad en la segunda mitad del siglo XVIII al recaer sobre ellos la construcción y refacción de los sistemas de defensa, embarcaciones y armas. Esto muestra los cambios que se operaron en Cartagena tras la abolición del situado, y también puede ser un indicio de que a pesar de que la crisis económica de la ciudad fue general, algunos sectores la sintieron con mayor fuerza.

En conclusión, al analizar los sectores sociales y económicos que participaron como ahorradores de la Caja, podemos afirmar que el objetivo perseguido por las autoridades locales de desarrollar el hábito del ahorro entre los sectores populares se cumplió sólo en parte al lograr vincular dos grupos importantes para este proyecto: las mujeres y los menores. No obstante, no sucedió lo mismo con los artesanos, considerado un grupo clave en esta iniciativa estatal.

Las posibilidades de ahorro de la gente común y corriente estaban supeditadas a los salarios que recibían en condición de trabajadores, o a los pequeños márgenes de ganancia que les dejaban negocios particulares como la pesca, las ventas al por menor y la producción artesanal. Aunque no contamos con estadísticas sistematizadas sobre los salarios devengados en el siglo XIX, poseemos algunos datos que pueden ser útiles. Por ejemplo, durante la primera mitad de ese siglo los salarios y jornales se mantuvieron estancados y muchas veces decrecieron, como fue el caso de los empleados públicos, sector que se vio afectado por la precariedad del tesoro nacional. ${ }^{58}$ Esto llevó a que a finales de la década de 1840 el gobierno nacional rebajara los estipendios que recibían algunos empleados pú-

${ }^{57}$ Solano, "Sistema", 2013, pp. 92-139.

${ }^{58}$ Solano, "Formas", 2010, pp. 157-180. 
blicos como los intendentes generales de los distritos de Hacienda, jueces de Hacienda y jueces de circuito, quienes en 1849 recibían los siguientes sueldos mensuales: intendente general del distrito de Hacienda de Cartagena, 120 pesos; juez de Hacienda, 100 pesos; juez de circuito, 46.6 pesos, y auxiliar de tesorería del culto de la diócesis de Cartagena, 24 pesos. ${ }^{59}$ Por su parte, los comisarios de policía recibían un jornal de menos de dos reales por día; un empleado comercial, 3.3 reales diarios, y un trabajador simple, entre tres y cuatro reales diarios. ${ }^{60} \mathrm{~A}$ lo largo de cuatro décadas los jornales se habían mantenido prácticamente estáticos pues en 1809 los cargadores ganaban dos reales; peones, carreteros y remeros ganaban tres reales; armeros y oficiales de herreros devengaban cuatro reales diarios, y los maestros herreros ganaban ocho reales. ${ }^{61}$

Si comparamos los sueldos de los empleados comerciales y los jornaleros con los de los comisarios de policía, nos damos cuenta de que aquellos estaban en mejores condiciones económicas. Expresión de la precariedad de los salarios de los comisarios fue que en 1844 las personas escogidas para desempeñar esos cargos en Barranquilla se negaron aduciendo que el sueldo de seis pesos mensuales "los colocaba en peores consideraciones sociales que las otorgadas a un jornalero, pues aquel sueldo era inferior a la sumatoria de los jornales de este al mes". ${ }^{62} \mathrm{Y}$ era cierto, pues se trataba de un jornal de 1.6 reales por día.

De igual forma, si examinamos los precios de algunos productos alimenticios básicos en 1849, comprobamos que los salarios devengados por un jornalero, un agente comercial y un comisario de policía no eran suficientes para vivir con holgura. Por ejemplo, la libra de cacao costaba un real y medio; la de chocolate, dos reales; la de arroz, 0.24 reales; la de frijol, 0.14 reales; la de queso, 1.2 reales; la de café, un real; la de tabaco en rama, dos reales; una botella de aceite de corozo, 1.6 real, y una de manteca de cerdo, dos reales; un coco, 0.14 reales. ${ }^{63}$ Otro elemento que demuestra lo bajo de los salarios que recibían muchas personas es comprobando el valor o arriendo de una casa en Cartagena. En 1850 se vendían dos casas bajas por un valor de 390 pesos cada una y un año antes se ofrecía en arriendo una casa alta por un valor de 25 pesos mensuales. ${ }^{64}$

${ }^{59}$ BLAA, El Porvenir, 5 y 15 de septiembre de 1849.

${ }^{60}$ BLAA, El Fanal, 15 de abril de 1849.

${ }^{61}$ Archivo General de la Nación, Colonia, Milicias y Marina, t. 47, fs. 477r.-526v., y t. 37, f. 930r.; Urrutia, "Precios", 2010, pp. 7-40, y Urrutia y Ruiz, "Ciento", 2010, pp. 154-189.

${ }_{62}$ Archivo del Concejo Municipal de Barranquilla, Libro de 1844, Correspondencia.

${ }^{63}$ BLAA, La República, 26 de diciembre de 1850.

${ }^{64}$ Ibid., 21 de marzo de 1850; El Fanal, 25 de enero de 1849, y El Porvenir, 15 de junio de 1849 . 
Entonces, al conocer los salarios que recibían algunos trabajadores oficiales, comerciales y los jornaleros, podemos afirmar que eran muy pocas las alternativas de ahorro que tenía la mayor parte de la población de Cartagena. Esta situación se reflejaba en las módicas sumas de dinero que la mayoría de las personas consignaban en la Caja. Por ejemplo, tres semanas después de haber comenzado los depósitos, el Semanario de la Provincia de Cartagena manifestaba que existían sólo 300 pesos depositados, lo que demostraba "la postración en que ha caído esta ciudad por lo que hace a la población y a la riqueza" ${ }^{65}$ De igual forma, en el informe rendido en julio de 1846 por la Junta de Inversión aclaraban que aunque los depósitos del semestre fueron por valor de 20488 pesos y 29 céntimos, 8455 pesos y 97 céntimos pertenecían a los fondos del canal del dique (brazo fluvial artificial que comunicaba la bahía de Cartagena con el cauce principal del río Magdalena), que por autorización de la Cámara provincial y acuerdo de la Junta Directiva, se colocaron en la Caja. De manera que el depósito de particulares sólo fue de 12032 pesos con 32 céntimos. Pero, aunque esta suma excedía en 6145 pesos y 37 céntimos a la que de igual procedencia se había acumulado en el semestre anterior, la Junta de Inversión aclaraba que:

Si establecemos una comparación entre dicha suma (12 032 pesos 32 céntimos) y el número de depositantes (410) y la población de la ciudad (que fijamos en 11000 habitantes), resultará que la acumulación del semestre está en 29 pesos con 34 céntimos por cada depositante y 1 peso 9 céntimos por cada habitante. Estos resultados, aunque bastantes lisonjeros, no lo son tanto si se considera que esa acumulación no se ha formado sólo con los menudos ahorros de las clases pobres, cuyo beneficio constituye el principal objeto de estas instituciones, sino que se compone en mucha parte de las sumas depositadas por personas acomodadas. ${ }^{66}$

En este informe de 1846, la junta de administradores señala que la escala de los depósitos por razón de su cuantía es la que aparece en el cuadro 3. De los 410 ahorradores, 128 sólo ahorraron en seis meses entre uno y cinco pesos. Además, 325 ni siquiera obtuvieron un peso de ganancia en el semestre, dado que sólo a los que ahorraron 100 pesos o más se les entregó la suma de un peso y 70 céntimos de ganancias mensualmente. Es decir, era muy poco lo que recibía de provecho la mayor parte de los ahorradores de la Caja, por ser tan bajos sus ahorros. Esto es, sin duda, un hecho indicativo de la crisis económica por la que atravesaba Cartagena durante la primera mitad del siglo XIX (véase cuadro 3).

${ }^{65}$ BLAA, SPC, 21 de julio de 1844.

${ }^{66}$ Ibid., 19 de julio de 1846. 
CUADRO 3. ESCALA DE LOS DEPÓSITOS

POR RAZÓN DE SU CUANTÍA, 1846

\begin{tabular}{lclr}
$\begin{array}{l}\text { Monto de dinero } \\
\text { ahorrado }\end{array}$ & Mhorradores & $\begin{array}{c}\text { Monto de dinero } \\
\text { ahorrado }\end{array}$ & Ahorradores \\
De 2 reales a 1 peso & 8 & De 90 a 100 & 6 \\
De 1 a 5 pesos & 128 & De 100 a 200 & 45 \\
De 5 a 10 & 35 & De 200 a 300 & 14 \\
De 10 a 20 & 29 & De 300 a 400 & 7 \\
De 20 a 30 & 40 & De 400 a 500 & 2 \\
De 30 a 40 & 10 & De 500 a 600 & 1 \\
De 40 a 50 & 19 & De 700 a 800 & 3 \\
De 50 a 60 & 24 & De 800 a 900 & 1 \\
De 60 a 70 & 26 & De 900 a 1000 & 1 \\
De 70 a 80 & 2 & De 1000 a 2000 & 4 \\
De 80 a 90 & 4 & De 3000 a 4000 & 1 \\
\hline
\end{tabular}

Fuente: BLAA, SPC, 19 de julio de 1846.

Desafortunadamente, la información suministrada por la Junta de Administradores de la Caja no especifica la capacidad de ahorro de los diferentes sectores socioeconómicos. En este informe no aparece, por ejemplo, cuánto podía ahorrar semanalmente un comerciante, un abogado, un hacendado, un artesano, una pulpera o una planchadora. Sólo contamos con datos parciales, como los suministrados por la Caja de Ahorro de Mompós en 1847, que comunicaba a la Junta de Inversión que los depósitos que se realizaron el 5 de septiembre ascendieron a 555 reales (véase cuadro 4 ).

Las cifras del cuadro 4, aunque incompletas, permiten observar que sastres y costureras en Mompós, al igual que en Cartagena, eran sectores representativos de los artesanos como ahorradores de la Caja, y que algunos podían ahorrar la cantidad de nueve y diez pesos, lo que muestra que estaban en mejores condiciones económicas que algunos funcionarios públicos. En el caso de los zapateros su capacidad de ahorro era menor que la de los dos primeros, lo que evidencia lo heterogéneo que era el sector de los artesanos en cuanto a sus ingresos. El que logró depositar una cantidad mayor fue el escribiente, lo que es un reflejo de la diferencia que existía entre los ingresos que recibía un trabajador calificado y uno que no lo era.

Sin embargo, no podemos afirmar a partir de este caso que las cantidades depositadas por cada uno de estos sectores eran iguales semanalmente. Podían variar o podía suceder que sólo depositaran sus ahorros una sola 
CUADRO 4. DEPOSITANTES Y CUANTÍA

DE LA CAJA DE AHORROS DE MOMPÓS

\begin{tabular}{lcc}
\hline Ocupaciones & Cantidad & Ahorros (en reales) \\
Directores de escuela & 1 & 16 \\
Sastres & 1 & 88 \\
Costureras & 1 & 80 \\
Eclesiásticos & 1 & 25 \\
Escribientes & 1 & 344 \\
Zapateros & 1 & 2 \\
Total & 6 & 555 \\
\hline
\end{tabular}

Fuente: BLAA, $S P C, 12$ de septiembre de 1847.

vez en el semestre. Lo que sí es frecuente es que cuando en los depósitos aparecen hacendados, negociantes, abogados o una institución, el monto es mayor que cuando lo hacen menores, empleados, sastres, cocineras, lavanderas, costureras u otros. Por ejemplo, el 31 de diciembre de 1848 hubo diez depósitos por un valor de 1020.71 pesos, y los depositantes fueron un abogado, una casada, dos empleados, un esclavo, un establecimiento público, un hacendado, dos menores y una viuda, mientras que tres semanas después fueron depositados 78.59 pesos por catorce ahorradores, entre los que figuraban una costurera, un sastre, un empleado y once menores. ${ }^{67}$

Hasta el momento hemos estudiado a los ahorradores y su capacidad de ahorro. Sin embargo, es pertinente preguntarse sobre los sectores que mayormente solicitaban créditos. La información entregada por la Junta de Administradores de la Caja entre junio de 1846 y diciembre de 1849 muestra que las actividades económicas y ocupaciones que más solicitaban préstamos eran el comercio, la agricultura, las artes y los oficios, las industrias, profesionales y las corporaciones públicas. En estos cinco semestres, el giro de la Caja fue de 423775.25 pesos, divididos en préstamos y descuentos. Los préstamos ascendieron a la suma de 263 856.12, y los descuentos sumaron 153919.13 pesos. Es decir, los primeros representaron $62.3 \%$ y los segundos 37.7 por ciento. ${ }^{68}$

Los mayores solicitantes de préstamos fueron los comerciantes, con la suma de 129697.12 pesos, lo que equivalía a 49.2\% de los préstamos. Los

${ }^{67}$ BLAA, El Fanal, 7 y 21 de enero de 1850.

${ }^{68}$ BLAA, SPC, 19 de julio de 1846; 18 de julio de 1847; 23 de enero 1848; 5 de agosto 1849 , y 29 de enero de 1849. 
seguían los propietarios, con un préstamo de 34772.96 pesos. En tercer lugar se situaban los empleados públicos, con una cantidad de 34585.32 pesos. También aparecían hacendados con 8374.53 pesos; artesanos, 6209.62 pesos y abogados, 4626.94 pesos. Estos grupos figuraban con $82.7 \%$. El restante $17.3 \%$ se dividía entre pulperos, militares, eclesiásticos, empleados en la educación, empresarios de obras públicas y otros.

Podemos señalar varios elementos en relación con los solicitantes de préstamos de la Caja. El primero es que las mujeres, a pesar de que figuraban como ahorradoras, en los cinco semestres analizados no aparecen solicitando préstamos. Caso contrario es el de los artesanos, sector que aunque no sobresalía como ahorrador sí lo hacía como solicitante de préstamos, lo que obedecía a que muchos de ellos, para cumplir con los contratos que les asignaban y en los que tenían que suministrar muchas veces los materiales que se necesitan en los trabajos, acudían a la Caja para que les solucionara la falta de capital. En ese sentido podemos decir que en este aspecto la Caja cumplió con uno de sus objetivos, que era brindar apoyo a los trabajadores pobres.

En el caso de los empleados públicos, la razón por la cual solicitaban préstamos era porque frecuentemente se les retrasaba el pago de sus salarios debido a la crisis del Tesoro Nacional, como lo informaba el periódico El Porvenir en 1849:

El Tesoro está a punto de caer en una bancarrota y nos amparamos en el cuadro doloroso de individuos cuya subsistencia precaria e insegura ha estado abandonada por más de seis u ocho meses a los recursos del cielo, pues a pesar del susodicho sobrante no se les ha abonado la cuota señalada a sus servicios, privándoseles de esta manera de gozar tranquila y sosegadamente en el seno de su familia el fruto de sus tareas. La administración no cuenta con los recursos necesarios para pagar a sus empleados. ${ }^{69}$

Esta situación obligaba a la mayoría de los empleados públicos a solicitar créditos. Por tanto, la Caja fue para este sector un soporte con el que sobrellevaban el estado de penuria en que se encontraba la economía de la ciudad, la cual, como consecuencia de la peste del cólera que la azotó en 1849, se encontraba en su peor estado en 1850, tal como lo observó Eliseus Reclus: "por las calles de la ciudad se ven cojos, tuertos, leprosos, enfermos de todas clases; jamás había visto tantos mendigos reunidos". ${ }^{70}$

En cuanto a los comerciantes, su papel protagónico como ahorradores y como solicitantes de préstamos de la Caja evidencia que, a pesar de la

${ }^{69}$ BLAA, El Porvenir, 1 de julio de 1849.

${ }^{70}$ Deavila y Guerrero, Cartagena, 2011, p. 204. 
crisis económica que enfrentaba la ciudad, el comercio era aún la principal actividad sobre la que descansaba la economía de Cartagena, y que aquellos eran el sector más importante de su estructura económica. Algunas décadas más tarde, sobre sus hombros recaería la recuperación económica de la ciudad.

\section{Final de la CAJa de Ahorros}

En 1853 la Caja de Ahorros dejó de funcionar por razones políticas y económicas. En el primer caso, la pugna que vivían liberales y conservadores desde 1849 se trasladó a la Caja, ocasionando serios enfrentamientos entre los ahorradores conservadores y las autoridades liberales. Al ser organizada la Caja por el Estado, la relación de esta con las facciones y partidos políticos fue una constante en los diez años de vida de la institución. Así, entre 1843 y 1849 los miembros de la Junta de Administradores estaban vinculados al partido conservador, y de 1850 a 1853 al liberal.

El enfrentamiento entre los partidos políticos llevó a que a partir de 1850 se iniciara una disputa entre un sector considerable de ahorradores, quienes pretendían que se les diera el derecho a los depositantes de nombrar a los 41 administradores de la Caja y a las autoridades locales liberales. Ese año los ahorradores conservadores elevaron una petición a la Cámara provincial firmada por más de cien depositantes, quienes tenían ahorrado cerca de 80000 pesos, en la que manifestaban que si no era aprobada, esto "conduciría a solicitudes masivas de retiro poniendo a la caja en una verdadera crisis". ${ }^{71}$

Ahora, aunque las razones políticas tuvieron un papel importante en la desaparición de la Caja, el factor determinante fue de orden económico, particularmente la decisión de emitir billetes desde 1846. Esta disposición afectó a la Caja al generarse un ambiente de escepticismo entre los ahorradores y los que solicitaban préstamos porque aquellos no contaban con el suficiente respaldo. Por ejemplo, en enero de 1850 unos ahorradores le solicitaban a los administradores no emitir nuevos billetes, sino en proporción a la cantidad que se tuviera para responder de su valor a la vista, porque: "de este modo volverá a restablecerse el crédito de los billetes, reobtendremos las ventajas de una institución que con tanto suceso comenzó a ensayarse". ${ }^{72}$ De igual forma, en 1851 el gobernador de la provincia manifestaba:

\footnotetext{
${ }^{71}$ BLAA, La República, 3 de octubre de 1850.
}

${ }^{72}$ BLAA, SPC, 2 de enero de 1850. 
Desde ahora llamamos la atención de la junta a la crítica posición en que se encuentran los billetes a consecuencia de la extraña e injustificable circunstancia de habérseles dejado en circulación sin la existencia en caja del fondo legal y necesario para su redención. Punto es este delicado e importante, que exige un pronto y acertado remedio, a fin de que se dicten medidas fuertes y eficaces que les haga recuperar el mérito que antes tenían. ${ }^{73}$

Aunque la Caja dejó de funcionar en 1853, la situación era dramática desde 1851, al especularse que se encontraba sin fondos. Algunos ahorradores llegaron a esta conclusión pues al intentar retirar sus peculios les dijeron que no se les podían entregar porque la Caja no tenía capital. Si bien los administradores negaban que "el no haberse cubierto todos los retiros que se han solicitado no ha dependido de mal estado del crédito del instituto sino de su misma organización", ${ }^{74}$ lo cierto fue que la emisión de billetes afectó su credibilidad y terminaría por llevarla al cierre, dándole fin a uno de los proyectos más interesantes que los sectores dirigentes, en su afán de generar nuevos hábitos sobre el trabajo y el ahorro, crearon en Cartagena en la década de 1840.

Un punto sobre el que no tenemos certeza es si efectivamente la Caja de Ahorros logró cambiar los hábitos de ahorro de los sectores populares de Cartagena. De lo que sí estamos seguros es de que, en medio de la crisis económica, la Caja fue un aliciente para muchos sectores, especialmente para comerciantes y empleados públicos. Asimismo, ayudó a regular las tasas de interés al ofrecer los préstamos a un menor costo a como los daban los particulares, como lo recordaba la Junta de Administradores en 1846 al manifestar que, a pesar de lo fuerte que era el interés establecido para sus préstamos y descuentos, era considerablemente menor al que antes de su establecimiento se exigía en el mayor número de transacciones análogas. ${ }^{75}$

\section{CONCLUSIONES}

La Caja de Ahorros de Cartagena se creó con el propósito de cambiar el comportamiento y las actitudes de los grupos pobres de la población, educando a la población en un estilo de vida marcado por la austeridad y la previsión. También aspiraba a estimular la actividad empresarial a través de la distribución de capital a bajo interés, pues todos los intentos por conseguir capitales para invertir en la economía se enfrentaban al rígido

\footnotetext{
${ }^{73}$ BLAA, La Democracia, 26 de enero de 1851.

74 Ibid.

${ }^{75}$ BLAA, SPC, 19 de julio de 1846.
} 
sistema de crédito de origen colonial (censos y capellanías). Por esta vía se pretendía aminorar los efectos de la crisis económica por la que atravesaba esta ciudad durante los primeros decenios de vida republicana.

Su existencia estuvo marcada por diversas dificultades (crisis económica, déficit del tesoro del Estado, decadencia del comercio de exportación, bajos salarios, inestabilidad política), más los problemas locales (caída de la población de Cartagena, pérdida del monopolio sobre el comercio exterior del país, fin del flujo del situado fiscal, cierre de las obras de defensa como espacio de demanda laboral). Un sector medio de la población formado por artesanos y pulperos sufrió esa situación, pues ya el Estado dejó de ser un espacio de contratación en el rubro de las obras de defensa y la naciente burocracia republicana no logró compensar esa decadencia. Además, esta estuvo sometida a los avatares de las finanzas públicas y al posible estancamiento y rebaja de los sueldos en concordancia con las crisis fiscales.

El estudio de la Caja de Ahorros nos ha permitido examinar las diferentes actividades laborales desempeñadas por hombres y mujeres para su subsistencia, y su posible capacidad de ahorro. Al igual que lo que sucedía en otras partes de Latinoamérica, los mayores ahorradores eran los menores y las mujeres. En el caso de los hombres sobresalen los comerciantes, los abogados y los empleados públicos. Artesanos y militares tuvieron poca participación, pese a ser sectores clave en la estructura socioeconómica de Cartagena desde la segunda mitad del siglo XVIII. Para la gente común y corriente, cuyo nivel de vida dependía de un jornal o de ganancias ocasionales por oficios artesanales, las posibilidades de ahorro estaban supeditadas a los salarios. En consecuencia, esas posibilidades se restringieron debido a que durante la primera mitad de ese siglo los salarios y los jornales se mantuvieron estancados y muchas veces decrecieron.

Caso distinto es el de los sectores socioeconómicos que se vieron favorecidos por los préstamos, el comercio, la agricultura, las artes y los oficios, la industria, los profesionales y las corporaciones públicas. A pesar de que eran un grupo que figuraba como ahorrador, las mujeres no aparecen solicitando préstamos. Caso contrario es el de los artesanos, sector que aunque no sobresalía como de ahorradores, sí lo hacía como solicitantes de préstamos. En ese sentido podemos decir que la Caja cumplió con uno de sus objetivos, que consistía en brindar apoyo a los trabajadores pobres.

En 1853 la Caja de Ahorros dejó de funcionar por razones políticas y económicas. En el primer caso, la pugna que vivían liberales y conservadores desde 1849 se trasladó a la Caja, ocasionando serios enfrentamientos entre los ahorradores conservadores y las autoridades liberales. Ahora, aunque las razones políticas desempeñaron un papel importante en la desaparición de la Caja, el factor determinante fue de orden económico, 
particularmente la decisión de emitir billetes desde 1846. Esta disposición afectó a la Caja al generarse un ambiente de escepticismo entre los ahorradores y los solicitantes de préstamos porque aquellos no contaban con el suficiente respaldo.

\section{FUENTES CONSULTADAS}

\section{Archivos}

ACMB Archivo del Concejo Municipal de Barranquilla, Barranquilla, Colombia.

AGN Archivo General de la Nación, Bogotá, Colombia.

AHA Archivo Histórico del Departamento del Atlántico, Barranquilla, Colombia.

BLAA Biblioteca Luis Ángel Arango, Bogotá, Colombia.

\section{Hemerografia}

El Fanal, Cartagena, Colombia, 1849-1850.

El Porvenir, Cartagena, Colombia, 1849.

Gaceta de Bolívar, Cartagena, Colombia, 1872.

La Democracia, Cartagena, Colombia, 1851.

La República, Cartagena, Colombia, 1850.

Semanario de la Provincia de Cartagena, Cartagena, Colombia, años 1840, 1841, 1842, $1843,1844,1845,1846,1847,1848,1849$ y 1850.

\section{Bibliografía}

Aguilera, María y Adolfo Meisel, Tres siglos de historia demográfica de Cartagena de Indias, Cartagena, Banco de la República, 2009.

Arango Jaramillo, Mario, Judas Tadeo Landínez y la primera bancarrota colombiana (1842), Bogotá, Hombre Nuevo, 1981.

Botero, María, "Moneda y banca en una economía aurífera. La región de Antioquia (Colombia), 1850-1890", América Latina en la Historia Económica, Instituto de Investigaciones Dr. José María Luis Mora, núm. 35, 2011, México, pp. 53-81.

Caballero, Tomás, "Entre las ventas forzosas y la usura: el mercado del crédito en Barranquilla entre 1849-1886", Historia Caribe, Universidad del Atlántico, núm. 13, 2008, pp. 229- 252.

, "Créditos, monedas, comerciantes y prestamistas. El mercado financiero en Barranquilla entre 1849 y 1903”, Historia Caribe, Universidad del Atlántico, núm. 18, 2011, pp. 145-164. 
Castro, Beatriz, Caridad y beneficencia. El tratamiento de la pobreza en Colombia 18701930, Bogotá, Universidad Externado de Colombia, 2007.

Conde, Jorge, Buscando la nación. Ciudadanía, clase y tensión racial en el Caribe colombiano, 1821-1855, Medellín, La Carreta, 2009.

Correa, Juan, "Banca y región en Colombia, 1850-1880”, Revista de Economía Institucional, Universidad Externado de Colombia, vol. 11, núm. 20, Bogotá, 2009, pp. 15-44.

CRuz, Maribel de la, "Remates y venta de bienes desamortizados en Colombia. El caso del Estado Soberano de Bolívar, 1861-1875", América Latina en la Historia Económica, Instituto de Investigaciones Dr. José María Luis Mora, vol. 21, núm. 1, 2014.

Deavila, Orlando y Lorena Guerrero (comps.), Cartagena vista por los viajeros siglos XVIII-XX, Cartagena, Alcaldía de Cartagena de Indias/Universidad de Cartagena, 2011.

Fernández, Alfonso, "La participación de los sectores populares en la vida política de la Provincia de Cartagena, 1821-1850”, tesis doctoral, España, Universidad Pablo de Olavide, 2010.

Flórez, Roicer y Sergio Paolo Solano "Educando al buen ciudadano: el papel de las guardias nacionales en la provincia de Cartagena, Colombia, 1832-1857", Anuario de Estudios Americanos, Escuela de Estudios Hispanoamericanos-CSIC, vol. 67, núm. 2, 2010, pp. 605-633

Helg, Aline, Libertad e igualdad en el Caribe colombiano, 1770-1835, Medellín, Universidad EAFIT, 2011.

Hensel, Franz, Vicios, virtudes y educación moral en la construcción de la república, 18211852, Bogotá, Universidad de los Andes, 2006.

Junguito, Roberto, "Las finanzas públicas en el siglo Xix", Adolfo Meisel y María T. Ramírez (eds.), Economía colombiana del siglo XIX, Bogotá, Fondo de Cultura Económica/Banco de la República, 2010, pp. 41-197.

Jurado, JuAn, Vagos, pobres y mendigos. Contribución a la historia social colombiana, 17501850, Medellín, La Carreta, 2004.

Kalmanovitz, SAlomón, "Consecuencias económicas de la independencia en Colombia”, Revista de Economía Institucional, Universidad Externado de Colombia, vol. 10, núm. 19, 2008, pp. 207-233.

y EDWIN LÓPEZ, Las cuentas nacionales de Colombia en el siglo XIX, Bogotá, Universidad Externado de Colombia, 2009.

Kuethe, Allan, "Las milicias disciplinadas en América" en Allan Kuethe y Juan Marchena (eds.), Soldados del rey. Ejército borbónico en América colonial en vísperas de la independencia, Valencia, Universitat Jaume I, 2005, pp. 101-126.

LÓPez-Uribe, María y DiAna GÜIZA, "La Caja de Ahorros: una aproximación a los patrones de ahorro en Bogotá, 1846-1865”, Centro de Estudios sobre Desarrollo Económico, Bogotá, Universidad de los Andes, 2011. 
Marchena, JuAn, La institución militar en Cartagena de Indias, 1700-1810, Sevilla, Escuela de Estudios Hispanoamericanos, 1982, pp. 268-271.

Martínez, Ángel, "Las cajas de ahorros españolas en el siglo XIX: entre la beneficencia y la integración en el sistema financiero", Revista de Historia Económica, Cambridge University Press/Universidad Carlos III, vol. XVIII, núm. 3, 2000, pp. 585-628, en <http://e-archivo.uc3m.es/bitstream/10016/2162/1/RHE-2000-XVIII3-Martinez.pdf>. [Consulta: 23 junio de 2013.]

"Los montes de piedad y las cajas de ahorros españolas en el siglo XIX (1835-1875)", ponencia, XIV International Economic History Congress, Helsinki 2006, en 〈http://www.helsinki.fi/iehc2006/papers2/Soto.pdf>. [Consulta: 17 de junio de 2013.]

"Las Cajas de Ahorros en las provincias de Ultramar: la Caja de Ahorros de San Juan Bautista, 1865-1879”, ponencia, Congreso Internacional de Historia de las Cajas de Ahorros, Murcia, octubre de 2008, en <http://www.um.es/congresos/cajahorro/documentos/P_ASoto.pdf $>$. [Consulta: 11 de diciembre de 2012.]

Mateo, Graciela, "Una propuesta institucional a la usura: el Monte de Piedad de Buenos Aires", ponencia, Congreso Internacional de Historia de las Cajas de Ahorros, Murcia, octubre de 2008, en <http://www.um.es/congresos/cajahorro/ documentos/P_ASoto.pdf $>$. [Consulta: 11 de diciembre de 2012.]

Meisel, Adolfo, "El patrón metálico 1821-1879” en El Banco de la República. Antecedentes, evolución, estructura, Bogotá, Banco de la República, 1990, pp. 3-31.

“Los Bancos de Cartagena, 1874-1925”, Lecturas de Economía, Universidad de Antioquia, núms. 32-33, 1990, Medellín, pp. 69-96.

"¿Situado o contrabando?: la base económica de Cartagena de Indias y el Caribe colombiano a fines del siglo de las luces" en Haroldo Calvo y Adolfo MeIsel (eds.), Cartagena de Indias en el siglo XVIII, Cartagena, Banco de la República, 2005, pp. 61-124. blica, 2009.

¿Por qué perdió la Costa Caribe el siglo XX?, Cartagena, Banco de la Repú-

e Irene SAlazar, "La desamortización en el Caribe colombiano: una reforma urbana liberal, 1861-1881", Cuadernos de Historia Económica y Empresarial, Banco de la República, núm. 30, Cartagena, 2011.

Molina, Fernando, Empresarios colombianos del siglo XIX, Bogotá, Banco de la República/El Áncora, 1998.

Múnera, Alfonso, El fracaso de la nación. Región, clase y raza en el caribe colombiano: 17171810, Bogotá, Banco de la República/El Áncora, 1998, pp. 53-110.

O’Byrne, Alex, "El desabastecimiento de géneros agrícolas en la Provincia de Cartagena de Indias a fines del periodo colonial”, Historia Crítica, Universidad de los Andes, núm. 50, 2013, pp. 59-78.

Pérez, Sonia, Los hijos del trabajo. Los artesanos de la ciudad de México, 1780-1853, México, Universidad Autónoma Metropolitana/El Colegio de México, 2005. 
Pombo, Lino De (comp.), Recopilación de leyes de la Nueva Granada, Bogotá, Imp. de Zoilo Salazar, 1845.

Quijada, Mónica, “¿Qué nación? Dinámicas de la nación en el imaginario hispanoamericano” en Antonio Annino y François-XAVier Guerra (coords.), Inventando la nación. Iberoamérica, siglo XIX, México, Fondo de Cultura Económica, 2003, pp. 287-315.

Ripoll, María Teresa, La elite en Cartagena y su tránsito a la república. Revolución política sin renovación social, Bogotá, Universidad de los Andes, 2006.

Rojas, RAFAEL, Las repúblicas de aire. Utopia y desencanto en la revolución de Hispanoamérica, México, Taurus, 2009, pp. 319-359.

Romero, María, "El Monte de Piedad de México: origen y desarrollo de la institución”, ponencia, Congreso Internacional de Historia de las Cajas de Ahorros, Murcia, octubre de 2008 en <http://www.um.es/congresos/cajahorro/documentos/P_ MERomero.pdf $>$. [Consulta: 12 de junio de 2013.]

SAFFORD, FrANK, El ideal de lo práctico. El desafío de formar una elite técnica y empresarial en Colombia, Bogotá, Universidad Nacional/El Áncora, 1989.

Sagastume, Tania, Trabajo urbano y tiempo libre en la ciudad de Guatemala, 1765-1840, Ciudad de Guatemala, Universidad de San Carlos, 2008.

Serrano, José Manuel, Fortificaciones y tropas. El gasto militar en Tierra Firme, 17001788, Sevilla, Universidad de Sevilla, 2004.

"Economía, rentas y situados en Cartagena de Indias, 1761-1800”, Anuario de Estudios Americanos, Escuela de Estudios Hispanoamericanos-CSIC, vol. 63, núm. 2, 2006, pp. 75-96.

Solano, Sergio Paolo, "Empresarios, proyectos de modernización e imaginarios sociales en la provincia de Cartagena durante la primera mitad del siglo XIX", Historia y Cultura, Universidad de Cartagena, núm. 3, 1995, pp. 9-38.

"Formas salariales y salario justo en el Caribe colombiano, 1850-1930", Amauta, Universidad del Atlántico, núm. 15, 2010, pp. 157-180.

“Artesanos, raza, Estado y liberalismo en Colombia, 1770-1850”, Encuentros Latinoamericanos, Universidad de la República, vol. VI, núm. 1, 2012, pp. 5-60. "Oficios, economía de mercado, hábitos de consumo y diferenciación social. El artesanado en Colombia, 1850-1930” en Sonia PÉrez Toledo (ed.), Trabajo, trabajadores y participación popular. Estudios sobre México, Guatemala, Colombia, Perú y Chile, siglos XVIII y XIX, Barcelona, Anthropos/Universidad Autónoma Metropolitana, 2012, pp. 113-144.

, "Sistema de defensa, artesanado y sociedad en el Nuevo Reino de Granada. El caso de Cartagena de Indias, 1750-1810", Memorias, Universidad del Norte, vol. 10, núm. 19, 2013, pp. 92-139.

y ROICER FLÓREZ, "Ordenamiento territorial y conflictos jurisdiccionales en el Bolívar Grande (Colombia), 1800-1886”, Historia Caribe, Universidad del Atlántico, núm. 13, 2008, pp. 67-121. 
"Política y trabajo. Debates sobre las normas jurídicas y las relaciones laborales de servidumbre en el Bolívar Grande (Colombia) en el siglo XIX", Revista de Estudios Sociales, Universidad de los Andes, núm. 45, 2013, pp. 16-28.

Sowell, DAVID, "La Caja de Ahorros de Bogotá, 1846-1865” en Germán MejíA et al., Colombia en el siglo XIX, Bogotá, Planeta, 1999, pp. 217-250.

Teitelbaum, VAnesa, Entre el control y la movilización. Honor, trabajo y solidaridades artesanales en la ciudad de México a mediados del siglo XIX, México, El Colegio de México, 2008.

Tovar, Hermes, "La historiografía sobre Cartagena de Indias en el siglo XviII" en HAroldo Calvo y Adolfo Meisel (eds.), Cartagena de Indias y su historia, Cartagena, Universidad Jorge Tadeo Lozano/Banco de la República, 1998, pp. 21-79.

Urrutia, Miguel, "Precios y salarios urbanos en el siglo XiX" en Adolfo Meisel y MARÍA Ramírez (eds.), Economía colombiana del siglo XIX, Bogotá, Fondo de Cultura Económica/Banco de la República, 2010, pp. 7-40.

y Mauricio Ruiz, "Ciento setenta años de salarios reales en Colombia”, Ensayos sobre Política Económica, Banco de la República, vol. 28, núm. 63, 2010, pp. 154-189. 